\title{
Educational Process International Journal
}

- 00

ISSN: 2147-0901 | e-ISSN: 2564-8020 | www.edupij.com

Educational Process: International Journal • Volume 10 • Issue $1 \bullet 2021$

\section{Relationships among childhood experiences, happiness and social media addictions in adolescents}

Yasin Demir

To cite this article: Demir, Y. (2021). Relationships among childhood experiences, happiness and social media addictions in adolescents. Educational Process: International Journal, 10(1), 13-26. http://dx.doi.org/10.22521/edupij.2021.101.2

To link to this article: $h t t p: / / d x . d o i . o r g / 10.22521 / e d u p i j .2021 .101 .2$

ORCID

Yasin Demir (1) https://orcid.org/0000-0002-2456-1449 


\title{
○
}

EDUPIJ • Volume $10 \bullet$ Issue $1 \bullet 2021 \bullet$ pp. 13-26.

\section{Research Article \\ Relationships among childhood experiences, happiness and social media addictions in adolescents}

\author{
Yasin Demir \\ Department of Psychology, Faculty of Humanities and Social Sciences, \\ Kahramanmaras Istiklal University, Turkey
}

\begin{abstract}
Background/purpose - The use of social media has become commonplace among adolescents. However, excessive use of social media causes addiction in some cases. In this context, it is considered important to investigate the factors related to social media addiction. The aim of this study is to investigate the relationships among childhood experiences, happiness, and social media addiction in adolescents.

Materials/methods - In the study, correlations between childhood experiences, happiness, and social media addiction among adolescents were tested with the structural equation model. The research involved 314 adolescents, and the Social Media Disorder Scale (SMDS), The Oxford Happiness Questionnaire Short Form (OHQ-SF), and the Childhood Experiences Questionnaire (CEQ) were used as data collection tools. SPSS 21 and AMOS programs were used for data analysis.

Results - The results of the path analysis indicated that negative childhood experiences negatively and directly affect happiness, whilst happiness negatively and directly affects social media addictions, negative childhood experiences positively and indirectly affect social media addictions, negative childhood experiences negatively affects happiness, and unhappiness positively affects social media addiction.

Conclusion - The current study's results have shown that negative perceived childhood experiences can negatively affect individuals emotionally and behaviorally during adolescence.
\end{abstract}

Keywords - Childhood experiences, happiness, social media addiction, adolescent.

Received May 6, 2020; Accepted December 3, 2020; Published Online March 17, 2021

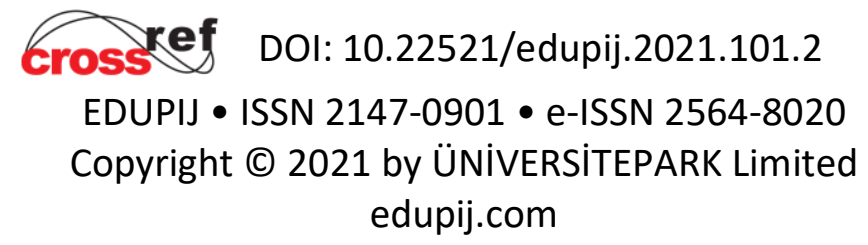

CORRESPONDENCE Yasin Demir yasin.demir@istiklal.edu.tr $\bigotimes$ Department of Psychology, Faculty of Humanities and Social Sciences, Kahramanmaras Istiklal University, 46050, Kahramanmaras, Turkey.

This work is licensed under a Creative Commons Attribution-NonCommercial 4.0 International License (https://creativecommons.org/licenses/by-nc/4.0/), where it is permissible to download and share the work provided it is properly cited. 


\section{Introduction}

It was reported that the number of active social media users exceeded four billion in 2021 (54\% of the approximate global population) (Kemp, 2021). In the aforementioned study, the same rate was reported as being $71 \%$ for Turkey. In a study conducted by the Turkish Statistical Institute, it was determined that Internet usage in Turkey was mostly for the purposes of social media access (Türkiye İstatistik Kurumu [Turkish Statistical Institute], 2018). The high level of social media usage has forced researchers to conduct studies on this issue. It has been stressed that the increase in the popularity of social media has been due to the adoption of social media by mobile devices and mobile network operators, thereby increasing access independent of time or space (Şahin \& Yağcl, 2017), and the popularity of several leading social media sites (Hawi \& Samaha, 2017).

Studies reported that social media applications change the way people communicate, interact and socialize with each other around the world (Louati \& Hadoussa, 2021; Sriwilai \& Charoensukmongkol, 2016). Despite the various benefits provided by social media, it is clear that some individuals, especially adolescents, become addicted to social media (Koc \& Gulyagci, 2013), even using mobile social media access whilst walking, shopping, or performing other activities (Sriwilai \& Charoensukmongkol, 2016). Although no formal identification has yet been made, social media addiction, also called problematic social media usage (Bányai et al., 2017; Durak, 2018), compulsive social media usage (Song \& Kim, 2017), excessive social media usage (Yu et al., 2018), and pathological social media usage (Holmgren \& Coyne, 2017) can be defined as the excessive use of social media, the desire to constantly check social media accounts, inability to stop using social media despite trying, and experiencing feelings of being tense and/or aggressive when unable to access social media (Kuss \& Griffiths, 2011). It has been reported that individuals who are addicted to social media usually tend to use social media with an extreme urge which they are unable to control (Andreassen, 2015). This might indicate that the dimensions of social media addiction have reached serious levels.

\section{Literature review}

It has been emphasized that social media is considered to be an indispensable tool for virtual social relations and virtual communication among adolescents. (Hawi \& Samaha, 2017; Koc \& Gulyagci, 2013; Sriwilai \& Charoensukmongkol, 2016). Researchers have explained the excessive use of social media by individuals with reasons such as personality traits, fear of missing out on developments, solitude, social inadequacy, and a fear of negative assessment (Biolcati, et al., 2018; Blackwell et al., 2017; Jeri-Yabar et al., 2019; Karakose \& Kocabas, 2006). Some researchers have emphasized that social media addiction results from emotional, relational, and performance-related problems (Marino et al., 2018; Mitra \& Rangaswamy, 2019). Furthermore, it has been determined that social media dependence negatively correlates with life satisfaction (Afsar, 2013) and happiness (Zinna \& Thanusri, 2018).

Happiness is a concept characterized by an excess of positive emotions in an individual's life, and their overall satisfaction with life (Diener et al., 2009). In previous studies, it was found that the life satisfaction of happy people was higher (Altinkurt \& Karakose, 2009; Demir \& Kutlu, 2016; Longstreet \& Brooks, 2017), and that happiness had a preventive effect on the development of social media addiction (Demir \& Kutlu, 2016) Thus, it could be suggested that happy individuals have a higher satisfaction with life and the development of 
social media addiction is lower in individuals who feel happy. On the other hand, it could be argued that unhappy individuals search for distractions in order to rid themselves of these undesired emotions, and as a result, they consider social media as a tool used to eliminate their unhappiness. Initially, the use of social media, through which the individual may consider to have a relieving effect, gradually increases to the point whereby the individual is no longer able to control their social media usage. Similar to other forms of dependency, a tolerance level develops in social media addiction, and the individual may experience serious unrest when they no longer have access to use social media.

Childhood experiences are considered a critical period in personality development, in understanding the external world, shaping the form of our relationships with other individuals, and forming a system of unique values (Demir \& Kutlu, 2016; Diener et al., 2009; Longstreet \& Brooks, 2017; Manap \& Durmuş, 2020). Previous studies have indicated that more than $90 \%$ of brain development occurs during the initial years of life, and emphasized that children create new schemes in every encounter and experience they have, and assign meanings to these schemes (Lenroot \& Giedd, 2006; Lumley \& Harkness, 2007). Therefore, it is possible to suggest that childhood experiences have an important effect on an individual's identity, in determining their philosophy in life, and in shaping the ideas and behaviors of the individual. In this context, it has been emphasized that negative experiences in childhood are an important determinant of several psychological disorders seen in adulthood (Cesur et al., 2018; Herrenkohl et al., 2013). Studies have demonstrated that childhood experiences play a critical role in social phobia (Gibb et al., 2007), depression (Spinhoven et al., 2010; Wright et al., 2009), substance abuse (Malkus, 1995; Siyez et al., 2012), and also personality development (Spinhoven et al., 2010). It has also been reported that childhood is an important period in the development of social competence (Hamarta et al., 2009). Researchers have emphasized the correlation between childhood experiences and life satisfaction (Çeçen-Eroğul \& Türk, 2013). Thus, it could be suggested that individuals with negative childhood experiences have a relatively negative view of life. Therefore, it can be stated that perceptions about childhood experiences can affect the happiness of individuals (Kızıldağ \& Yıldırım, 2018).

Social media addiction is one of the most important recent issues, and has often been investigated by researchers (Balakrishnan \& Griffiths, 2017; Demirci, 2019; Hawi \& Samaha, 2018; Kuss, 2017; Turel et al., 2018). However, it cannot be suggested that the factors that affect social media addiction have been fully investigated. Thus, the aim of the current study is to investigate the direct effect of happiness on social media addiction among adolescents. Furthermore, the study aims to analyze the indirect effects of childhood experiences on social media addiction. It is anticipated that the current study will contribute to the literature as follows: Initially, it was considered that social media addiction is a field that requires investigation using a versatile approach, since the issue is comparatively novel and approximately 10 years have passed since the initial studies were published (van den Eijnden et al., 2016) and social media use has increased significantly among all social segments over what has been a very short period of time (Lim, 2018; Munkaila, \& Iddrisu, 2015; Slagoski, 2019). Second, it has often been observed that although the paired correlations between social media addiction and other variables have been analyzed in previous studies (Akın, 2012; Bilgin \& Taş, 2018; Longstreet \& Brooks, 2017; Phu \& Gow, 2019), the current study, where such variables are tested within the framework of a model, will be one of the first such studies in its field. Third, considering that several studies have reported on the results 
of social media addiction, it was considered that it would be significant to consider what factors may affect social media addiction such as childhood experiences, in contrast to the previously published research. Finally, it was considered that the current study would contribute to the intervention programs aimed at social media addiction.

Based on the proposed hypothetical model, negative childhood experiences directly affect happiness, and happiness directly affects social media addiction. On the other hand, negative childhood experiences affect social media addiction indirectly. The hypotheses related to childhood experiences, happiness, and social media addiction are as follows:

- H1: Negative childhood experiences directly and negatively affect happiness.

- H2: Happiness directly and negatively affects social media addiction.

- H3: Negative childhood experiences indirectly and positively affect social media addiction.

\section{Methodology}

\subsection{Study Group}

The study was conducted with ninth-, 10th- and 11th-grade students receiving their education at two different high schools in the eastern region of Turkey. Forms including measurement tools and sociodemographic questions were distributed to a total of 400 students. The responses from 26 students, who completed their forms with data missing or were randomly completed, were excluded from the analysis of the study. A further 60 of the remaining 374 students who submitted complete data stated that they did not have any social media accounts, and their data were thereby also excluded. Within the scope of the study, it was determined that 314 (84\%) of the 374 students reached in the study were actively users of at least one social media account, hence the study was conducted with the data obtained from these students.

A total of 314 adolescents ( $n=167,53.2 \%$ female, $n=147,46.8 \%$ male) attending various high schools in the Elazığ province in the east of Turkey in 2018, and who had at least one social media account actively used, participated in the current study. The participants' ages varied from 14 to 17 years old $(\bar{x}=15.73, S D=0.88)$. While 142 of the participants stated that they had one social media account, 89 stated that they had two social media accounts, 43 had three social media accounts, 21 had four social media accounts, and 19 of the participants stated that they had five social media accounts $(\bar{x}=2.02, S D=1.25)$. In total, 256 of the participants (81.5\%) owned a smartphone with Internet access. Of the participants, $208(66.2 \%)$ stated that they used social media every day, whilst $84(26.8 \%)$ used social media several times a week, and 22 of the participants (7\%) stated that they used it several times a month.

\subsection{Instruments}

Childhood Experiences Scale (CES): The CES was developed by Manap (2015), and consists of 13 items within three factors (family life, school experiences, and personal-social experiences) that include negative childhood experiences. The scale is a 5-point, Likert-type instrument (from $1=$ Always, to $5=$ Never). Confirmatory factor analysis demonstrated that the CES has acceptable fitness index values $\left(\chi^{2} / d f=2.03, \operatorname{RMSEA}=.059, \mathrm{AGFI}=.92\right.$, $\mathrm{CFI}=.95$, and $\mathrm{NFI}=.90)$. The Cronbach $\alpha$ internal consistency coefficient for the scale was .82 for the family life factor, .77 for school experiences, and .70 for personal-social experiences. These results indicate that the CES is a valid and reliable measurement 
instrument. Higher scores achieved on the CES indicate a high level of negative child experiences related to each factor.

Social Media Disorder Scale (SMDS): The SMDS was developed by van den Eijnden et al. (2016), and then subsequently adapted to the Turkish context by Savci et al. (2018). The scale consists of nine, 5-point, Likert-type items (from $1=$ Never to $5=$ Always). Confirmatory factor analysis showed that the SMDS was found to have acceptable compliance index values $\left(\chi^{2} / d f=1.951, \mathrm{RMSEA}=.07, \mathrm{GFI}=.94, \mathrm{CFI}=.94, \mathrm{IFI}=.94\right.$, and $\left.\mathrm{TLI}(\mathrm{NNFI})=.92\right)$. The factor load values of the scale's EFA ranged from .44 to .75. The Cronbach $\alpha$ internal consistency coefficient of the scale was .86 , whilst the test-retest reliability was found to be .81. These results show the SMDS to be a valid and reliable measurement tool. The SMDS was developed using the diagnostic criteria of DSM-V Internet Gaming Disorder. These items are related to addiction concepts such as tolerance development, and preoccupation and persistence, etc. Higher scores achieved from the SMDS indicate a high level of social media addiction.

Oxford Happiness Questionnaire-Short Form (OHQ-SF): The OHQ-SF was developed by Hills and Argyle (2002), and later adapted to the Turkish context by Doğan and Sapmaz (2012). The scale consists of a single factor with seven items As a result of confirmatory factor analysis, the OHQ-SF was found to have acceptable compliance index values $\left(\chi^{2} / d f=2.77, \mathrm{RMSEA}=.074, \mathrm{GFI}=.97, \mathrm{CFI}=.95\right.$, and IFI $\left.=.95\right)$. The factor load values of the scale's EFA range from .53 to .72 . The Cronbach $\alpha$ internal consistency coefficient of the scale was found to be .74 and the test-retest reliability .85 . These results show the OHQ-SF to be a valid and reliable measurement tool. Higher scores from the OHQ-SF indicate a high level of happiness.

\subsection{Procedure}

Written consent was obtained from the Elazığ Provincial Directorate of National Education prior to the study being conducted. The study was conducted during an available class hour at the schools with students who volunteered to take part, and who stated that they had at least one active social media account.

Following the application, the collected data were digitized and analyses conducted with the maximum likelihood method using Amos software. Prior to the analysis, the data were analyzed for the prerequisites of structural equation modeling (SEM) such as sample size, multicollinearity, normality, and outliers. It was calculated that correlation coefficients were below .90, VIF values were 1.16 for happiness, and 1.25 for childhood experiences (1.25 for school experiences, 1.29 for family life, and 1.11 for personal experiences). It was observed that the skewness values were between -0.162 and 1.698 , and that the kurtosis coefficients were between -0.76 and 2.188 . Then, the measurement models for each variable used in SEM were tested with confirmatory factor analysis. In the measurement instruments for the happiness scale and social media dependence, one proposed modification was applied in order to obtain acceptable fitness indices, with the modifications tested in the model. The confirmatory factor analysis findings were as follows: $\chi^{2} / d f=2.0605$, $\operatorname{RMSEA}=.058$, $\mathrm{SRMR}=.043, \mathrm{GFI}=.98, \mathrm{IFI}=.96, \mathrm{TLI}=.93$, and $\mathrm{CFI}=.96$ for happiness; $\chi^{2} / d f=2.638$, $\mathrm{RMSEA}=.072, \mathrm{SRMR}=.046, \mathrm{GFI}=.95, \mathrm{IFI}=.96, \mathrm{TLI}=.93$, and $\mathrm{CFI}=.96$ for social media dependence; $\chi^{2} / d f=2.940, \mathrm{RMSEA}=.079, \mathrm{SRMR}=.100, \mathrm{GFI}=.93, \mathrm{IFI}=.93, \mathrm{TLI}=.93$, and $\mathrm{CFI}=.93$ for negative childhood experiences. Based on these findings, it can be suggested 
that the data and measurement instruments exhibited acceptable values for SEM (Çokluk et al., 2012; Kline, 2015).

\section{Results}

First, the variables of the study were examined in terms of participant gender differences. When gender differences were addressed, the $t$-test results showed that female students $(M=19.58, S D=7.30)$ and male students $(M=18.47, S D=6.58)$ did not differ significantly on their levels of social media addiction $(t=1.410, p>.05)$. Similarly the female students $(M=22.57, S D=5.26)$ and male students $(M=23.39, S D=5.09)$ did not differ significantly on their levels of happiness $(t=1.409, p>.05)$.

Additionally, neither the female or male students differed significantly on all three dimensions of levels of their childhood experiences [family life: females $(M=5.56, S D=2.61$ ) and males $(M=5.71, S D=2.42, t=-.528, p>.05)$; personal-social experiences: females $(M=10.00, S D=3.72)$ and males $(M=10.21, S D=3.95, \quad t=-.487, p>.05)$; school experiences: females $(M=6.99, S D=3.77)$ and males $(M=6.99, S D=3.70, t=-.12, p>.05)]$.

After $t$-test analysis was employed to compare any differences according to the participants' gender, correlation analysis was applied to test the correlations between childhood experiences, happiness, and social media dependence. The correlations and descriptive statistics for the variables are presented in Table 1.

Table 1. Correlations and Descriptive Statistics of Variables

\begin{tabular}{lrrrrc}
\hline \multicolumn{1}{c}{ Variables } & 1 & 2 & 3 & 4 & 5 \\
\hline (1) Social Media Addiction & 1 & $-.39^{* *}$ & $.21^{* *}$ & $.21^{* *}$ & $.17^{* *}$ \\
(2) Happiness & & 1 & $-.30^{* *}$ & $-.16^{* *}$ & $-.23^{* *}$ \\
(3) Childhood Experiences_Family Life & & & 1 & $.19^{* *}$ & $.31^{* *}$ \\
(4) Childhood Experiences_Personal-Social & & & & 1 & $.25^{* *}$ \\
$\quad$ Experiences & & & & & \\
(5) Childhood Experiences_School Experiences & & & & & 1 \\
$M$ & 19.0 & 22.96 & 5.63 & 10.10 & 6.99 \\
$S D$ & 6 & & & & \\
S & 6.98 & 5.19 & 2.52 & 3.82 & 3.73 \\
\hline$* * .00, p<.01$ & & & & &
\end{tabular}

As can be seen from Table 1, analysis demonstrates that there was a negative correlation found to exist between social media addiction and happiness $(r=-.39, p<.01)$, and positive correlations with all dimensions of negative childhood experiences [family life $(r=.21, p<.01)$, personal-social experiences $(r=.21, p<.01)$, and school experiences $(r=.17, p<.01)]$. It was observed that the correlations between the variables were below .90 , thus, it can be suggested that there was no multicollinearity problem (Çokluk et al., 2014; (Karakose, Kocabas, Yesilyurt, 2014; Kline, 2005). The proposed hypothetical model was then tested, and the findings presented in Figure 1. 


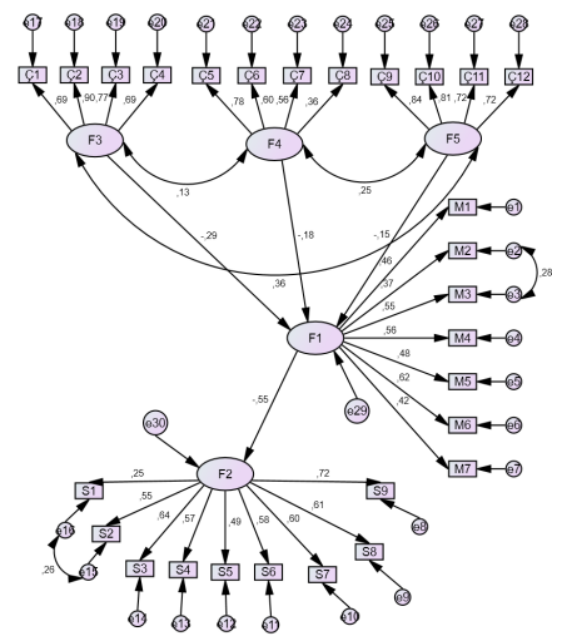

Figure 1. Standardized factor loading for the proposed hypothetical model

[F3 = Childhood Experiences_Family Life; F4 = Childhood Experiences_School

Experiences; F5 = Childhood Experiences_Personal-Social Experiences; F1 = Happiness; F2 = Social Media Addiction]

A review of the fitness indices for the hypothetical model revealed the following findings: $\chi^{2}=595.844, d f=341$, and $\chi^{2} / d f=1.747$. Also the following calculations were obtained: $\mathrm{GFI}=.88, \mathrm{IFI}=.90, \mathrm{TLI}(\mathrm{NNFI})=.89, \mathrm{CFI}=.90, \mathrm{SRMR}=.071$, and $\mathrm{RMSEA}=.049$. Analysis of the fitness indices for the model demonstrated that the model had an acceptable level of fitness. Thus, it can be stated that the hypotheses in the hypothetical model were confirmed.

\section{Discussion, Conclusion and Suggestions}

In the current study, correlations between childhood experiences, happiness, and social media addiction among adolescents were tested with the structural equation model. The study's findings demonstrated that negative childhood experiences directly and negatively affected happiness. It was also found that happiness directly and negatively affected social media addiction. Furthermore, it was concluded that negative childhood experiences indirectly and positively affected social media addiction. Accordingly, as the negative childhood experiences increased among adolescents, their happiness levels decreased, and as the level of happiness decreased, their social media addiction increased. This finding demonstrated that their happiness had a direct and negative effect on their childhood experiences, which had an indirect effect on the social media addiction among adolescents.

Individuals with negative childhood experiences tend to perceive the world as an insecure place (Read \& Bentall, 2012). These individuals may also have a pessimistic approach to life (Meyer \& Carver, 2000). First, these individuals may not have achieved satisfaction in their family life. As negative childhood experiences increase, the joy in social relations has been shown to decrease (Marshall \& Cooke, 1999). One important source of happiness is an abundance of positive childhood experiences. When happy individuals are analyzed in general, it has been observed that they had positive childhood experiences (Lee \& Schafer, 2020; Roisman et al., 2004). Negative childhood experiences are the basis for mood disorders (Battle et al., 2004; Jaworska-Andryszewska \& Rybakowski, 2019), and unhappy individuals are more prone to unhealthy sources of happiness; for example, substance abuse, alcohol and other dependency behaviors could be observed (Saini \& Puri, 
2016). Thus, negative childhood experiences may lead to unhappiness in other periods of an individual's life.

Negative childhood experiences could lead to a search for positive interpersonal relationships. Individuals with negative experiences in real-life environments may consider social media as a means of compensation (Nezakati et al., 2015). Indeed, one of the criteria of social media addiction is the use of social media to avoid incidents that lead to stress in daily life. Social media applications allow users to achieve as many social experiences as they desire within a short period of time. In this context, excessive social media usage can lead to dependency.

The results of the current study have shown that negative perceived childhood experiences can negatively affect individuals emotionally and behaviorally during adolescence. One of the reasons that individuals become addicted to social media usage can be low levels of happiness. Relationships in real-life social settings should be supported, nurtured, and encouraged. Future studies could investigate the effect of self-perception, solitude, and depressive tendencies on the correlation between childhood experiences and social media addiction.

As in every study, the current study also has certain limitations. The limitations of the current study include the use of self-reporting scales, the fact that the population of the study was from a single city, and that the sample included only adolescent participants. The study's findings should therefore be evaluated based on these limitations, and future studies should minimize these limitations in order to achieve accurate inferences.

\section{Declarations}

Author Contributions The article was written by one author, and he has read and approved the published on the final version of the article.

Conflicts of Interest The author declare no conflict of interest.

Funding None.

Ethical Approval All procedures performed in studies involving human participants were in accordance with the ethical standards of the institutional and/or national research committee and with the 1964 Helsinki Declaration and its later amendments or comparable ethical standards.

Data Availability Statement The data that support the findings of this study are available from the corresponding author upon request. The data are not publicly available due to privacy or ethical restrictions.

Acknowledgments None.

ORCID

Yasin Demir (iD) https://orcid.org/0000-0002-2456-1449 


\section{References}

Afsar, B. (2013). The relation between Internet and social media use and the demographic and clinical parameters, quality of life, depression, cognitive function and sleep quality in hemodialysis patients: social media and hemodialysis. General Hospital Psychiatry, 35(6), 625-630. https://doi.org/10.1016/i.genhosppsych.2013.05.001

Akın, A. (2012). The relationships between Internet addiction, subjective vitality, and subjective happiness. Cyberpsychology, Behavior, and Social Networking, 15(8), 404410. https://doi.org/10.1089/cyber.2011.0609

Altinkurt, Y., \& Karakose, T. (2009). Illköğretim okulu müdürlerinin etik liderlik davranışlarına ilişkin öğretmen görüşleri. Dumlupınar Üniversitesi Sosyal Bilimler Dergisi, 24, 269280. https://app.trdizin.gov.tr/makale/T1RVd056TXo/ilkogretim-okulu-mudurlerininetik-liderlik-davranislarina-iliskin-ogretmen-gorusleri

Andreassen, C. S. (2015). Online social network site addiction: A comprehensive review. Current Addiction Reports, 2, 175-184. https://doi:10.1007/s40429-015-0056-9

Balakrishnan, J., \& Griffiths, M. D. (2017). Social media addiction: What is the role of content in YouTube? Journal of Behavioral Addictions, 6(3), 364-377. https://doi.org/10.1556/2006.6.2017.058

Bányai, F., Zsila, Á., Király, O., Maraz, A., Elekes, Z., Griffiths, M. D., Schou Andreassen, C., \& Demetrovics, Z. (2017). Problematic social media use: Results from a large-scale nationally representative adolescent sample. PLoS One,12(1), Article e0169839. https://doi.org/10.1371/journal.pone.0169839

Battle, C. L., Shea, M. T., Johnson, D. M., Yen, S., Zlotnick, C., Zanarini, M. C., Sanislow, C. A., Skodol, A. E., Gunderson, J. G., Grilo, C. M., McGlashan, T. H., \& Morey, L. C. (2004). Childhood maltreatment associated with adult personality disorders: Findings from the collaborative longitudinal personality disorders study. Journal of Personality Disorders, 18(2), 193-211. https://doi.org/10.1521/pedi.18.2.193.32777

Bilgin, O., \& Taş, ì. (2018). Effects of perceived social support and psychological resilience on social media addiction among university students. Universal Journal of Educational Research, 6(4), 751-758. http://dx.doi.org/10.13189/ujer.2018.060418

Biolcati, R., Mancini, G., Pupi, V., \& Mugheddu, V. (2018). Facebook addiction: Onset predictors. Journal of Clinical Medicine, 7(6), Article 118. https://doi.org/10.3390/jcm7060118

Blackwell, D., Leaman, C., Tramposch, R., Osborne, C., \& Liss, M. (2017). Extraversion, neuroticism, attachment style and fear of missing out as predictors of social media use and addiction. Personality and Individual Differences, 116, 69-72. https://doi.org/10.1016/i.paid.2017.04.039

Çeçen Eroğul, A. R., \& Türk, Ş. B. (2013). An investigation of the relationship between childhood trauma experience of adolescents and the anger expression styles, self esteem, life satisfaction. International Journal of Human Sciences, 10(1), 1421-1439. https://www.j-humansciences.com/ojs/index.php/ijhs/article/view/2559

Cesur, G., Sayrac, N., \& Korkmaz, E. (2018). The Role of mindfulness between childhood abuse and trait anxiety. Turkish Journal of Psychology, 33(81), 97-112. https://www.psikolog.org.tr/en/publications/yayinlar/10.31828/tpd1300443320180 000m000006.pdf

Çokluk, Ö., Şekercioğlu, G., \& Büyüköztürk, ş. (2012). Sosyal bilimler için çok değişkenli istatistik: SPSS ve LISREL uygulamaların [Multivariate statistics for social sciences: SPSS and LISREL applications]. Pegem Akademi. 
Demir, Y., \& Kutlu, M. (2016). Relation between social interaction anxiety and happiness: Intermediary role of solitude among university students. Gazi University Journal of Gazi Educational Faculty, 36(1), 195-210. http://www.gefad.gazi.edu.tr/en/download/article-file/312842

Demirci, I. (2019). The adaptation of the Bergen Social Media Addiction Scale to Turkish and its evaluation of relationship with depression and anxiety symptoms. Anatolian Journal of Psychiatry, 20(SI1), 15-23. http://doi.org/10.5455/apd.41585

Diener, E., Scollon, C. N., \& Lucas, R. E. (2009). The evolving concept of subjective well-being: The multifaceted nature of happiness. In E. Diener (Ed.), Assessing well-being (pp. 67100). Springer.

Doğan, T., \& Sapmaz, F. (2012). Oxford mutluluk ölçeği Türkçe formunun psikometrik özelliklerinin üniversite öğrencilerinde incelenmesi [Examination of psychometric properties of the Turkish version form of the Oxford Happiness Questionnaire in university students]. Düşünen Adam The Journal of Psychiatry and Neurological Sciences, 25(4), 297-304. http://doi.org/10.5350/dajpn2012250401

Durak, H. Y. (2018). Modeling of variables related to problematic internet usage and problematic social media usage in adolescents. Current Psychology, 39, 1375-1387. https://doi.org/10.1007/s12144-018-9840-8

Gibb, B. E., Chelminski, I., \& Zimmerman, M. (2007). Childhood emotional, physical, and sexual abuse, and diagnoses of depressive and anxiety disorders in adult psychiatric outpatients. Depression and Anxiety, 24(4), 256-263. https://doi.org/10.1002/da.20238

Hamarta, E., Deniz, M. E., \& Saltalı, D. N. (2009). Attachment styles as a predictor of emotional intelligence. Educational Sciences: Theory \& Practice, 9(1), 195-229. http://oldsite.estp.com.tr/en/makale.asp?ID=372\&act=detay

Hawi, N. S., \& Samaha, M. (2017). The relations among social media addiction, self-esteem, and life satisfaction in university students. Social Science Computer Review, 35(5), 576-586. https://doi.org/10.1177/0894439316660340

Hawi, N., \& Samaha, M. (2018). Identifying commonalities and differences in personality characteristics of Internet and social media addiction profiles: Traits, self-esteem, and self-construal. Behaviour \& Information Technology, 38(2), 110-119. https://doi.org/10.1080/0144929X.2018.1515984

Herrenkohl, T. I., Hong, S., Klika, J. B., Herrenkohl, R. C., \& Russo, M. J. (2013). Developmental impacts of child abuse and neglect related to adult mental health, substance use, and physical health. Journal of Family Violence, 28(2), 191-199. https://doi.org/10.1007/s10896-012-9474-9

Hills, P., \& Argyle, M. (2002). The Oxford happiness questionnaire: A compact scale for the measurement of psychological well-being. Personality and Individual Differences, 33(7), 1073-1082. https://doi.org/10.1016/S0191-8869(01)00213-6

Holmgren, H. G., \& Coyne, S. M. (2017). Can't stop scrolling!: pathological use of social networking sites in emerging adulthood. Addiction Research \& Theory, 25(5), 375382. https://doi.org/10.1080/16066359.2017.1294164

Jaworska-Andryszewska, P., \& Rybakowski, J. K. (2019). Childhood trauma in mood disorders: neurobiological mechanisms and implications for treatment. Pharmacological Reports, 71(1), 112-120. https://doi.org/10.1016/j.pharep.2018.10.004

Jeri-Yabar, A., Sanchez-Carbonel, A., Tito, K., Ramirez-delCastillo, J., Torres-Alcantara, A., Denegri, D., \& Carreazo, Y. (2019). Association between social media use (Twitter, 
Instagram, Facebook) and depressive symptoms: Are Twitter users at higher risk? International Journal of Social Psychiatry, 65(1), 14-19. https://doi.org/10.1177/0020764018814270

Karakose, T., \& Kocabas, I. (2006). The effect of teachers' expectations on job satisfaction and motivation in private and public schools. Journal of Theory and Practice in Education, 2(1), 3-14. https://dergipark.org.tr/en/pub/eku/issue/5441/73869

Karakose, T., Kocabas, I., Yesilyurt, H. (2014). A quantitative study of school administrators' work-life balance and job satisfaction in public schools. Pakistan Journal of Statistics, 30, 1231-1241.

https://www.researchgate.net/publication/289002648 A quantitative study of sch ool administrators' work-life balance and job satisfaction in public schools

Kemp S. (2021, January 27). Digital 2021: Global Overview Report. Datareportal https://datareportal.com/reports/digital-2021-global-overview-report

Kızıldağ, S., \& Yıldırım, ì. (2018). Testing a couple burnout model. Turkish Psychological Counseling and $\quad$ Guidance Journal, 8(49), 116. http://turkpdrdergisi.com/index.php/pdr/article/view/494

Kline, R. B. (2015). Principles and practice of structural equation modeling. Guilford.

Koc, M., \& Gulyagci, S. (2013). Facebook addiction among Turkish college students: The role of psychological health, demographic, and usage characteristics. Cyberpsychology, Behavior, and Social Networking, 16(4), 279-284. https://doi.org/10.1089/cyber.2012.0249

Kuss, D. J. (2017). OP-59: Social networking sites and social media addiction: Insights from current empirical research. Journal of Behavioral Addictions,6(S1), 29-30. https://doi.org/10.3390/ijerph14030311

Kuss, D. J., \& Griffiths, M. D. (2011). Online social networking and addiction - a review of the psychological literature. International Journal of Environmental Research and Public Health, 8(9), 3528-3552. https://doi.org/10.3390/ijerph8093528

Lee, H., \& Schafer, M. (2020). Are positive childhood experiences linked to better cognitive functioning in later life?: Examining the role of life course pathways. Journal of Aging and Health, 33(3-4), 217-226. https://doi.org/10.1177/0898264320972547

Lenroot, R. K., \& Giedd, J. N. (2006). Brain development in children and adolescents: Insights from anatomical magnetic resonance imaging. Neuroscience \& Biobehavioral Reviews, 30(6), 718-729. https://doi.org/10.1016/j.neubiorev.2006.06.001

Lim, K.-Y. (2018). An exploration of the use of Facebook by legislators in Taiwan. Issues and Studies, 54(3). https://doi.org/10.1142/S1013251118400052

Longstreet, P., \& Brooks, S. (2017). Life satisfaction: A key to managing internet \& social $\begin{array}{llll}\text { media } \text { addiction. Technology in Society, 50, } & \text { 77. }\end{array}$ https://doi.org/10.1016/j.techsoc.2017.05.003

Louati, H., \& Hadoussa, S. (2021). Study of Social media impacts on social capital and employee performance-evidence from Tunisia Telecom. Journal of Decision Systems. Advance online publication. https://doi.org/10.1080/12460125.2021.1872142

Lumley, M. N., \& Harkness, K. L. (2007). Specificity in the relations among childhood adversity, early maladaptive schemas, and symptom profiles in adolescent depression. Cognitive Therapy and Research, 31(5), 639-657. https://doi.org/10.1007/s10608-006-9100-3

Malkus, B. M. (1995). Family dynamic and structural correlates of adolescent substance abuse: A comparison of families of non-substance abusers and substance abusers. 
Journal of Child \& Adolescent Substance Abuse, 3(4), 39-52. https://doi.org/10.1300/J029v03n04_03

Manap, A. (2015). Development of childhood experiences questionnaire: The study of validity and reliability. The Journal of International Social Research, 8(41), 822-826. https://www.sosyalarastirmalar.com/cilt8/sayi41 pdf/4sosyoloji psikoloji felsefe/m anap abdullah.pdf

Manap, A., \& Durmuş, E. (2020). Development of digital parental awareness scale. Inonu University Journal of the Faculty of Education, 21(2), 978-993. https://doi.org/10.17679/inuefd.711101

Marino, C., Gini, G., Vieno, A., \& Spada, M. M. (2018). A comprehensive meta-analysis on problematic Facebook use. Computers in Human Behavior, 83, 262-277. https://doi.org/10.1016/i.chb.2018.02.009

Marshall, L. A., \& Cooke, D. J. (1999). The childhood experiences of psychopaths: A retrospective study of familial and societal factors. Journal of Personality Disorders, 13(3), 211-225. https://doi.org/10.1521/pedi.1999.13.3.211

Meyer, B., \& Carver, C. S. (2000). Negative childhood accounts, sensitivity, and pessimism: A study of avoidant personality disorder features in college students. Journal of Personality Disorders, 14(3), 233-248. https://doi.org/10.1521/pedi.2000.14.3.233

Mitra, R., \& Rangaswamy, M. (2019). Excessive social media use and its association with depression and rumination in an Indian young adult population: A mediation model. Journal of Psychosocial Research, 14(1), 223-231. https://doi.org/10.32381/JPR.2019.14.01.24

Munkaila, A. \& Iddrisu, A. (2015). Impact of social media sites on the academic performance of students in Polytechnic of Ghana. International Journal of Economics, Commerce and Management, 3(11), 1021-1035. https://doi.org/10.11648/i.ajad.20170204.13

Nezakati, H., Amidi, A., Jusoh, Y. Y., Moghadas, S., Aziz, Y. A., \& Sohrabinezhadtalemi, R. (2015). Review of social media potential on knowledge sharing and collaboration in tourism industry. Procedia-Social and Behavioral Sciences, 172, 120-125. https://doi.org/10.1016/i.sbspro.2015.01.344

Phu, B., \& Gow, A. J. (2019). Facebook use and its association with subjective happiness and loneliness. Computers in Human Behavior, 92, 151-159. https://doi.org/10.1016/j.chb.2018.11.020

Read, J., \& Bentall, R. P. (2012). Negative childhood experiences and mental health: theoretical, clinical and primary prevention implications. The British Journal of Psychiatry, 200(2), 89-91. https://doi.org/10.1192/bjp.bp.111.096727

Roisman, G. I., Tsai, J. L., \& Chiang, K.-H. S. (2004). The emotional integration of childhood experience: physiological, facial expressive, and self-reported emotional response during the adult attachment interview. Developmental Psychology, 40(5), 776-789. https://doi.org/10.1037/0012-1649.40.5.776

Şahin, C., \& Yağcl, M. (2017). Social media addiction scale - adult form: The reliability and validity study. Ahi Evran University Journal of Kırşehir Education Faculty (KEFAD), 18(1), 523-538. https://kefad.ahievran.edu.tr/Kefad/Archivelssues/Detail/1d57a43b-ee5b-e71180ef-00224d68272d

Saini, D. S., \& Puri, S. S. (2016). Preventive measures of substance abuse problem in India. Indian Journal of Health \& Wellbeing, 7(7), 757-762. http://www.ischolar.in/index.php/ijhw/article/view/120178 
Savci, M., Ercengiz, M., \& Aysan, F. (2018). Turkish adaptation of the social media disorder scale in adolescents. Archives of Neuropsychiatry, 55(3), 248-255. https://doi.org/10.5152/npa.2017.19285

Siyez, D. M., Gürçay, E. G., \& Yüncü, Z. (2012). The perceptions of adolescents towards their childhood family life experiences with regard to their having substance use disorder or not. Anatolian Journal of Psychiatry, 13(4), 299-305. https://alphapsychiatry.com/en/the-perceptions-of-adolescents-towards-their-childhood-familylife-experiences-with-regard-to-their-having-substance-use-disorder-or-not-131230

Slagoski, J. (2019). Professional learning practices and beliefs of an online community of English language teachers. Contemporary Issues in Technology and Teacher Education, 19(1), 97-116. https://citejournal.org/volume-19/issue-1-19/currentpractice/professional-learning-practices-and-beliefs-of-an-online-community-ofenglish-language-teachers/

Song, S.-G., \& Kim, D.-Y. (2017). How was your trip experience while you were obsessed with social media? The influence of compulsive social media usage on trip experience. In R. Schegg, \& B. Stangl (Eds.), Information and Communication Technologies in Tourism 2017 (pp. 669-681). Springer. https://doi.org/10.1007/978-3-319-51168948

Spinhoven, P., Elzinga, B. M., Hovens, J. G., Roelofs, K., Zitman, F. G., van Oppen, P., \& Penninx, B. W. (2010). The specificity of childhood adversities and negative life events across the life span to anxiety and depressive disorders. Journal of Affective Disorders, 126(1-2), 103-112. https://doi.org/10.1016/j.jad.2010.02.132

Sriwilai, K., \& Charoensukmongkol, P. (2016). Face it, don't Facebook it: impacts of social media addiction on mindfulness, coping strategies and the consequence on emotional exhaustion. Stress and Health, 32(4), 427-434. https://doi.org/10.1002/smi.2637

Turel, O., He, Q., Brevers, D., \& Bechara, A. (2018). Delay discounting mediates the association between posterior insular cortex volume and social media addiction symptoms. Cognitive, Affective, \& Behavioral Neuroscience, 18, 694-704. https://doi.org/10.3758/s13415-018-0597-1

Türkiye İstatistik Kurumu. (2018). Hanehalkı bilişim teknolojileri kullanım araştırması, 2018 [Household information technology usage research, 2018]. Report 27819. https://data.tuik.gov.tr/Bulten/Index?p=Hanehalki-Bilisim-Teknolojileri-(BT)Kullanim-Arastirmasi-2018-27819

van den Eijnden, R. J., Lemmens, J. S., \& Valkenburg, P. M. (2016). The social media disorder scale. Computers in Human Behavior, 61, 478-487. https://doi.org/10.1016/i.chb.2016.03.038

Wright, M. O. D., Crawford, E., \& Del Castillo, D. (2009). Childhood emotional maltreatment and later psychological distress among college students: The mediating role of maladaptive schemas. Child Abuse \& Neglect, 33(1), 59-68. https://doi.org/10.1016/i.chiabu.2008.12.007 
Yu, L., Cao, X., Liu, Z., \& Wang, J. (2018). Excessive social media use at work: exploring the effects of social media overload on job performance. Information Technology \& People, 31(6), 1091-1112. https://doi.org/10.1108/ITP-10-2016-0237

Zinna, M. A. A., \& Thanusri, R. (2018). Materialism, happiness and social media addiction among adolescents. The International Journal of Indian Psychology, 6(2), 5-15. https://ijip.in/articles/materialism-happiness-and-social-media-addiction-amongadolescents/

\section{About the contributor}

Yasin Demir is Assistant Professor of Department of Psychology in the Kahramanmaras Istiklal University (Turkey). His main research interests include technology addiction, psychological counseling, career development, developmental psychology, and positive psychology. He has published extensively in the international journals and also presented papers in the field of psychological counseling. 